Vol. 9 (4): 647-650 (2019)

\title{
ARABIA GOAT'S BREED WEIGHT EVOLUTION IN SEMI-ARID REGION OF WESTERN ALGERIA
}

\author{
Samia Meliani $^{1 *}$, Koula Doukani ${ }^{1}$, Akila Bourabah ${ }^{2}$, Khelil Sofiane Raouf $^{1}$, Djilali Guemour ${ }^{1}$ \\ ${ }^{I}$ Nature and Life Sciences Faculty, Ibn Khaldoun University-Tiaret (14000), Algeria; \\ ${ }^{2}$ Veterinary Sciences Institute, Ibn Khaldoun University - Tiaret (14000), Algeria; \\ *Corresponding author Samia Meliani, email: melianisamia@ hotmail.com;
}

Received August 2019; Accepted September 2019; Published October 2019;

DOI: https://doi.org/10.31407/ijees9408

\begin{abstract}
The aim of this study was to determine the influence of sex and type of birth in Arabia goat breed kids raised in western Algeria. Our study was conducted in the Livestock Technical Institute of Ksar-Chellala in Tiaret region between 2016 and 2017. For this study, eighty-one kids were weighted monthly since birth until 360 days old. The influence of sex, age and type of birth on the kid's weight was analyzed statistically. In this work, birth mean weight for males was about $3.16 \pm 0.58 \mathrm{~kg}$ significantly $(\mathrm{p}<0.05)$ higher than $2.88 \pm 0.50$ for females, the mean weights at birth for all kids was $3.06 \pm 0.57 \mathrm{~kg}$. The birth type influenced significantly $(\mathrm{p}<0.05)$ the kid's weight between birth and 30 days old, single born kids were heavier $3.38 \pm 0.51 \mathrm{~kg}$ than twins $2.89 \pm 0.53 \mathrm{~kg}$ and triplets $2.60 \mathrm{~kg}$. In this work, both sex and birth type influenced significantly the weight at birth in kids.
\end{abstract}

Keywords: Algerian goats breed, Kids, Birth type, Production 